\title{
Maritime Trade and Societal Transitions in the Western Indonesian Archipelago: Samudra-Pasai at the Dawn of the European Age (c. 1200-1500)
}

\author{
Kenneth R. Hall
}

Ball State University

\begin{abstract}
This study is the substantial update to a journal article published in 1981, focal on the first northeast Sumatra fourteenth- and fifteenthcentury Islamic Sultanate Samudra-Pasai port-of-trade. In doing so the study represents the significant transitions in Indian Ocean history that were substantially influenced by Michael Pearson's scholarship. Samudra-Pasai was a notable eastern Indian Ocean fourteenth- and fifteenth-century Straits of Melaka international maritime stopover that competed against the west-central Malay Peninsula-based Melaka emporium for regional commercial prominence prior to Portuguese seizure of Melaka in 1511. Past histories are based on the several surviving contemporary maritime sojourner accounts, Chinese dynastic records, and the local sixteenth-century Hikayat Raja-Raja Pasai dynastic chronicle. Recent anthropological surveys of the Sumatra upstream pair with new archaeological recoveries, which include dated Arabic script inscribed dynastic tombstones, to mandate a re-evaluation of upstream downstream networking that was the basis of SamudraPasai's over two-century sovereignty. This study moves beyond initially innovative 1970s conceptions of early Straits of Melaka upstreamdownstream networking in its incorporation of Michaviom Pearson's
\end{abstract}


adaptive characterizations of Indian Ocean port-of-trade coastline littorals, and introduces the importance of newly focal offshore communities as these are now prominent in the most recent Indian Ocean scholarship.

\section{Key words}

Aceh, Duarte Barbosa, Hikayat Raja-Raja Pasai, Ibn Battuta, Java, Ma Huan, Melaka, Minangkabau, Ming China, Samudra-Pasai, Straits of Melaka, Odoric (Father), Sumatra, Tome Pires, Zheng He

\section{INTRODUCTION}

Indian Ocean maritime trade dispersed during the tenth through the thirteenth centuries as the previous mainstream Middle East to India to China routes diffused and greater numbers and different types of traders pursued a variety of regional products into the wider Southeast Asia region. No longer was the southeast end of the Straits of Melaka the vital transitional point of the Indian Ocean to South China Sea passageway, which had been controlled by the southeastern Sumatra thalassocracy of Srivijaya and Java from the seventh to the twelfth centuries. ${ }^{1}$

An 1178 Chinese source declared that:

Of all the wealthy foreign lands that have great store of precious and varied goods, none surpasses the realm of Ta-shih (the "Arabs"/"Middle Easterners"). Next to them comes She p'o (Java), while San-fo-chi (Srivijaya) is third; many others come in the next rank. ${ }^{2}$

\footnotetext{
1 See 0. W. Wolters, The Fall of Srivijaya in Malay History, Ithaca, New York, Cornell University Press: 1970; Billy Kee Long So, "Dissolving Hegemony or Changing Trade Paterns? Images of Srivijaya in the Chinese Sources of he Twelfth and Thirteenth Centuries," Journal of Southeast Asian Studies, 29, 2 (1998), 295-308.

2 Paul Wheatley, The Golden Khersonese (Kuala Lumpur: 1961), 63; O. W. Wolters, Early Indonesian Commerce (lthaca, New York: Cornell University Press, 1967), 251, quoting Chu'u-fei in his Ling Wai Tai T'a, a work extensively incorporated into Chau Ju-kua's Chu fan-chih. See F. Hirth and W. W. Rockhill, Chau-Ju-kua (St. Petersburg: 1911).
} 
Shortly thereafter the primary Southeast Asia maritime stopovers shifted from southeast Sumatra to northeast Sumatra's pepper producing regions at the northern end of the Melaka Straits, to the Malay Peninsula - with linkage to the Thai and Burmese regions to the north, the central and southern Vietnam Cham coastline, and to intermediary north coast Java ports on the southern end of the Straits where spices and exotic jungle products arrived from the eastern Indonesian archipelago. As represented in Map 1, the favored maritime routes were, from the west, along the east coast of Sumatra through the Melaka Strait, and from the east, sailing north to south in the South China Sea along the Vietnam coastline from China to east coast Java, or alternatively from south China and northern Vietnam along the west coast of Borneo to north Java coast ports and westward to the Strait of Melaka passageway. A less-traveled alternate west coast Sumatra route in either direction used the Sunda Strait between Java and Sumatra to access the west Sumatra coastline, which was known to be a more dangerous navigational passageway than the favored east coast Sumatra route. Dangerous shoals and rock outcroppings prevented sailing directly east across the South China Sea from the Vietnam shoreline or by a western voyage from Borneo/Kalimantan to the Southeast Asia mainland. 


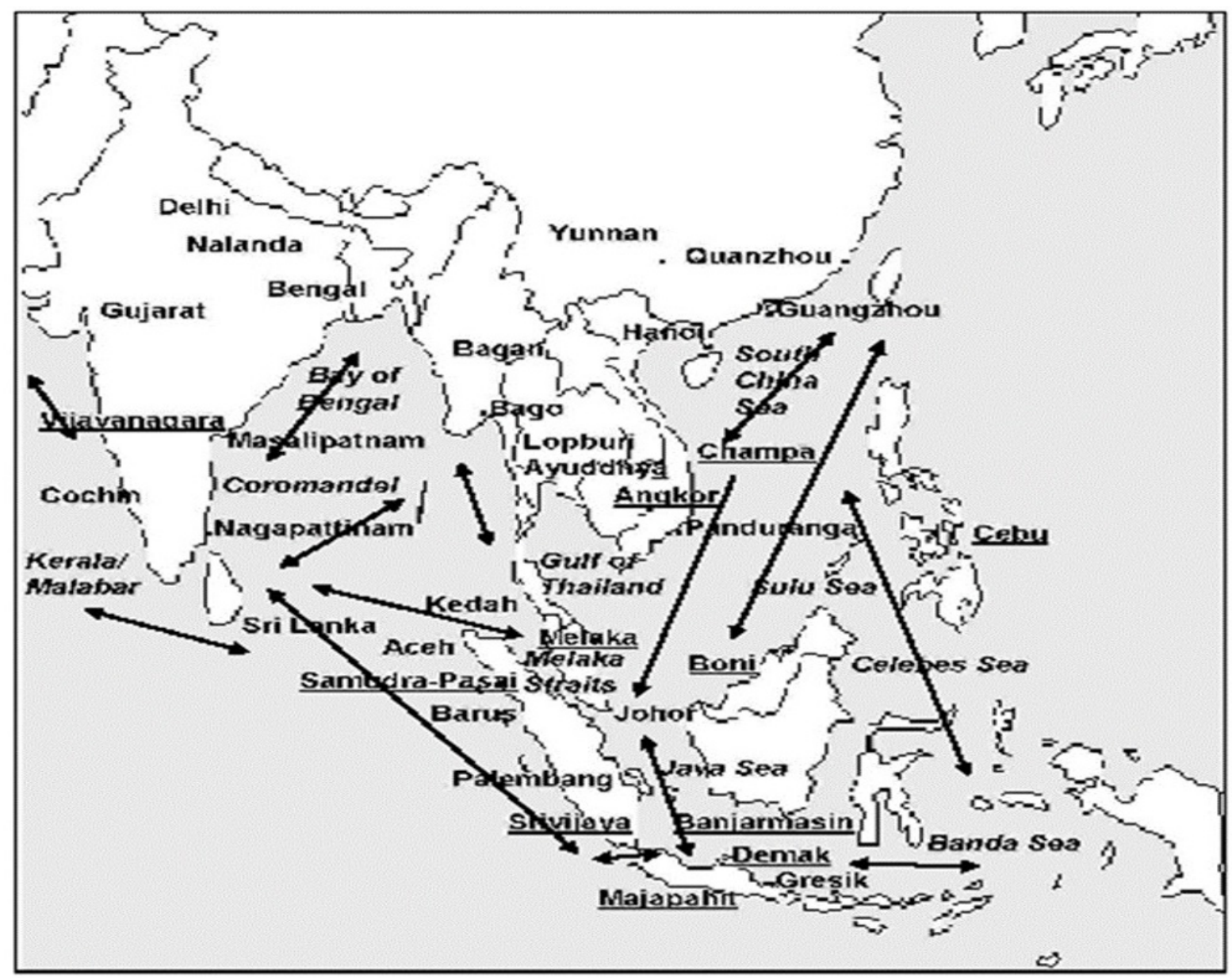

Map 1: South China Sea, Java Sea, and Straits of Melaka Extended Eastern Indian Ocean Maritime Trade Routes Based on Navigability, c. 1200-1500

\section{Samudra-Pasai and the China trade}

There were only two ports on the northern Sumatra coast invited by the newly empowered Yuan rulers to send tribute missions to China in the late thirteenth century. One was La$m u-l i$ (Lamuri/Ramni), a port on the northern tip of the island that was subsequently incorporated into the urban center of Aceh, where Middle Eastern sojourners powered by the seasonal monsoon winds came off the eastern Indian Ocean to make regular stopovers from the tenth century. ${ }^{3}$ The second was Su-mu-tu-la (Samudra), which eventually united with the nearby court of Pasai to become the prominent Samudra-Pasai

3 E. Edwards McKibben, "Beyond Sarndib: A Note on Lambri at the Northern Tip of Aceh," Indonesia, 46 (October 1988), 102-21. 
port polity, which during the thirteenth through the fifteenth centuries was the foremost northeast Sumatra coastline port of trade.

Samudra-Pasai first appeared in Chinese records consequent to a Yuan court diplomatic mission returning from India's southeast Coromandel coastline that made a 1282 stopover at Sa-mu-tu-la. The ruler of Sa-mu-tu-la subsequently sent two ministers, both Muslims, to accompany the Yuan envoys on their return voyage. ${ }^{4}$ Marco Polo claimed to have visited Sa-mu-tu-la shortly thereafter in 1292, but did not have much to say about the port except that its population had not as yet converted to Islam, and that it was settled by "primitive fishermen and farmers." 5 Based on evidence supplied by a gravestone dated 1296 attributed to a local "chief", Samudra's rulers are believed to have converted to Islam sometime between Marco Polo's 1292 visit and 1297, a conversion that was no doubt beneficial to Samudra becoming the favored north Sumatra intermediary port-of-call as host to Middle East and China-linked sojourners. ${ }^{6}$ Initially no more than a small settlement of maritime diaspora "fishermen" in the offseason, and less significant than the port of Lamuli/Ramni to its north, by the end of the fourteenth century Samudra would become the favored monsoon seasonal port-of-call frequented by foreign traders pursuing or trading eastern Indian Ocean products in northern Straits of Melaka regional ports, or as stopovers before mariners sailed onward to the east or west. According to the Hikayat Raja Pasai's retrospective court chronicle account, in the early fifteenth century Samudra-Pasai had been captured and sacked by a "tattooed-faced king of Nagur" leading raiders from the Nagur river upstream. Though Samudra-Pasai regained its independence thereafter, when the "Nagur" forces returned to their upstream, a dynastic feud followed. Ma Huan's early fifteenth-century account reported

\footnotetext{
4 Hill, 8.

5 Polo. Chapters 9-11 of Book III; see Kenneth R. Hall, "The Coming of Islam to the Archipelago: a Re Assessment" in Hutterer, ed., 213-31.
} 
that the Ming Admiral Zheng He had subsequently intervened and reestablished order in the Samudra-Pasai realm around 1413-1415. ${ }^{7}$

Why is it that Samudra-Pasai became the major northern Sumatra commercial hub in the fourteenth century over what would eventually be incorporated into the sixteenth-century Aceh sultanate? It is very tempting to use local conversion to Islam as the exclusive answer because the Hikayat Raja Pasai and the subsequent Sejarah Melayu chronicles of the Samudra-Pasai and Melaka courts preserve the legend that the first conversion of a state within the entire island realm took place in Samudra-Pasai, and view the success of both Samudra-Pasai and its successor Melaka as a direct consequence of this event. ${ }^{8}$

According to the Hikayat Raja Pasai, which was composed in its surviving version sometime before the Samudra-Pasai court was annexed into the Aceh realm in 1524, the Samudra court was founded one generation before the conversion of its ruler. ${ }^{9}$ The Hikayat relates a symbolic tale of the migration of the founder of the Samudra state from a

7 Ma Huan, 115 -18. A.H. Hill sees tension between a pro-Hindu Majapahit element and a pro-Islam faction in the Hikayat Raja Pasai (Hill, 7-10), but this conflict is more likely than between internal (upstream) and external (downstream) factions, as developed below.

8 Scholars have argued that the conversion to Islam by Sumudra-Pasai, Melaka, northern Java, and other early Malay world port-polities was done to encourage Indian Ocean merchants, themselves in some instances recent converts to Islam, to frequent their port. However, Melaka became a commercial power in the early fifteenth century despite Samudra-Pasai's wider recognition as a center of Islamic scholarship at that time. Indeed, Chinese sources record the shift of Java's spice trade to Melaka before the conversion of Melaka's rulers to Islam (see the Hsing-ch'a Sheng-lan, 1436, as translated in Groeneveldt, 210). It is apparent in the case of Melaka that the initial expansion of this new port was due to Chinese patronage; it was after the withdrawal of the Ming from an active presence in Southeast Asia that Melaka's rulers quickly converted to Islam, as if this was necessary for Melaka's survival as a major Southeast Asian port-of-trade [see C. Wake, "Malacca's Early Kings and the Reception of lslam," Journal of Southeast Asian History, 5, 2 (1964), 104-28]; R. O. Windstedt, "Outline of the Shellabear version of the Sejarah Melayu," JMBRAS, I6, 3 (1938), 1-225.

9 On the conversion of Sumudra-Pasai, see A. H. Hill, "The Coming of Islam to North Sumatra," Journal of Southeast Asian History, 4, 1 (1963), 6-21. Anthony Johns' emphasis on the role of the Sufi movement as an agent of conversion needs to be factored relative to early north Sumatra Islamic conversions. See A. H. Johns, "Islam in Southeast Asia: Reflections and New Directions," Indonesia, 19 (April 1975), 33-55. 
place to the north, possibly Lamuri/Ramni, and shortly thereafter Samudra became prominent. This local accounting stresses a foundational alliance between a downstream maritime adventurer and the native populations of the upstream hinterland as the source of the future ruler's success and Samudra-Pasia's subsequent prosperity. ${ }^{10}$ The Hikayat account has little interest in the commerce conducted at the SamudraPasai port, but is concerned with establishing the legitimacy of Samudra-Pasai's rulers as Islamic monarchs by narrating stories about a series of Samudra and Pasai sultans, many of whose names are inscribed on Islamic gravestones (most made-to-order in Gujarat) still to be found in the upstream of the Pasai River. ${ }^{11}$

\section{Early references to Samudra-Pasai's emerging} commercial prominence in external sources has led historians to propose that the original Samudra-Pasai center of power was on the Samudra-based Pasangan River, the longest river in the northeastern Sumatra coastline region, which provided convenient access to the emerging port-polity's upstream. Complicating this history, as noted all the Samudra-Pasai rulers' gravestones have been recovered in the now small village of Pasai in the intermediate downstream of the secondary Pasai River. ${ }^{12}$ Historians account for this discrepancy by arguing that the center of Samudra-Pasai's

10 See Hall, "The Coming of Islam," and the Sejarah Melayu's telling of this story in Brown, 40-49.

11 Hill, "Hikayat," 27. Some of the legends contained in the Hikayat can be identified as based on the retelling of Indian folktales, while some are segments of Malay folk legends. The use of popularly-known symbols is especially important in the stories' narration.

12 Elizabeth Lambourn, "Khutba and Muslim Network Networks in the Indian Ocean (Part II) - Timurid and Ottoman Engagements," in Kenneth R. Hall, ed., The Growth of NonWestern Cities: Primary and Secondary Urban Networking, c. 900-1900, Lanham, MD: Rowman and Littlefield/Lexington Books, 2011, 131-58; "Inscriptions as Artifact: New Perspectives on Tombstones and Samudra's Ruling Elite During the Fourteenth Century," paper draft incorporated into "Tombstones, Texts, and Typologies: Seeing Sources for the Early History of Islam in Southeast Asia," Journal of the Economic and Social History of the Orient, 5 (2008), 252-86; "Before Batu Aceh: The Formation of the Batu Aceh Tradition in Fifteenth Century Samudra-Pasai," Indonesia and the Malay World, 31.93 (2004), 211-48; "From Cambay to Pasai and Gresik: The Export of Gujarati Grave Memorials to Sumatra and Java in the Fifteenth Century," Indonesia and the Malay World, 31.90 (2003), 221-89. 
royal authority was from the beginning at Samudra, but was eventually moved to Pasai, likely to better protect the court against piracy and other raids from the sea. In the fifteenthcentury Melaka on the Malay Peninsula and Aceh on Sumatra's northern tip displaced Samudra-Pasai as the Melaka Straits most prominent ports-of-trade. ${ }^{13}$ The Melaka court chronicle traced the lineage of its sultanate and rightful succession as the heir to Samudra-Pasai; and Aceh subsequently annexed the Samudra-Pasai realm into its expansive sultanate.

Ibn Battuta's mid-fourteenth century description of the Samudra urban center depicts it as located inland from the coast; he estimated that he had traveled four miles upstream from the coast to Samudra, which was large and beautiful . . . surrounded by a wooden wall with wooden towers. ${ }^{14}$ Ibn Battuta's description is contradicted by Ma Huan, who visited in the early fifteenth century as a member of the Zheng $\mathrm{He}$ expeditions, and reported that there was no walled city in the Samudra area at that time. ${ }^{15}$ Ibn Battuta relates that though based somewhat upstream, the ruler of Samudra had full authority over the coastal port of Sarha, which was assigned to an "admiral" (laksamana) who ran the port's affairs as the Samudra ruler's agent. ${ }^{16}$

According to the Hikayat Rqja Pasai two or three generations after the foundation of the Samudra court it was conquered by Pasai. The urban center of Pasai is said by the Hikayat to have been initiated by a son of the first ruler of Samudra as the secondary court. Pasai's initial reference in the Yuan court records dates 1309, when three missions to the Mongol court by the then most prominent ports in the Melaka Straits region were said to have arrived from Champa [central Vietnam], Palembang [southeast Sumatra], and Pah-sih [Pasai in northeast Sumatra]. ${ }^{17}$ In his early fifteenth-century account of Zheng He's voyages, Ma Huan details internal conflict in

13Hill, "Hikayat," 12.

14lbn Battuta, 274.

15 Ma Huan, 115.

16 Ibn Battuta, 277. 
Samudra using the older Chinese Sa-mu-tu-la in reference to the shoreline realm. Subsequent Ming-era dynastic accounts state that order on the northern Sumatra coastline was restored when Chinese troops intervened on the fourth naval expedition of Zheng $\mathrm{He}(1413-1415) .{ }^{18}$ Repeated internal strife is a common feature in the local Hikayat storyline, said to be the product of Samudra's less powerful Pasai successor court, as the chronicle text explains the transfer of royal power from Samudra to Pasai as a consequence of a war between the two competing court centers, blamed on the Sultan of Samudra who was said to have brought on the war when he eloped with one of the Pasai court's women against the advice of a wise elderly official's counsel.

The Hikayat narrative also reports a subsequent fifteenthcentury Javanese naval attack on the then Samudra-Pasai polity. Although the raid is embellished in the Hikayat account as it ended in a Samudra-Pasai victory, there is no hint of a break in the Samudra-Pasai line of court authority until the realm ultimately fell to Aceh in the sixteenth century. ${ }^{19}$ In the early sixteenth century Javanese influence in Samudra-Pasai was said to have been considerable, as confirmed in the early sixteenth-century account by the then Portuguese Governor of Melaka written just prior to the Portuguese conqueror Alfonse de Albuquerque's 1511 successful attack on Melaka and his fleet's linked capture of a Javanese ship in the Straits. On board was the "king of Pasai," who informed D'Albuquerque that he was on his way to visit his relative the "king of Java" (likely the then Lord of Demak) to ask for soldiers and a fleet to

\footnotetext{
17 Hill, "Hikayat," 9. Note that the three referenced ports form an inclusive region that connected - or served as the "borderless" passage between the eastern Indian Ocean to the South China Sea in the minds of the Chinese.

18 Hill, "Hikayat," 27. Hill warns that such legends contained in the Hikayat are localizations of Indian folktales, and others segments of Malay folk legends rather than complete reality. The use of such popularly-known symbolic tales are argued to have been especially symbolically and thematically important in these stories' narration as they reinforced dynastic legitimacy.
}

19 Hill, "Hikayat," 13. 
assist him against one of his "governors" who had led a rebellion by a faction of the "king's" subordinate elite. ${ }^{20}$

It was not long thereafter that Aceh extended its power over Samudra-Pasai in 1524. The fall of Samudra-Pasai to Aceh was in part due to prolonged internal political strife. The late sixteenth-century Portuguese governor D'Albuquerque's report asserts that there was another major political crisis in Samudra-Pasai at the time of Melaka's fall to his father in 1511, which was soon followed by Portuguese conquest of Aceh as well. Sixteenth-century Ming records relate the local legend of a slave who killed the king of Samudra and enthroned his master, then killed his master and enthroned himself. Following the murder of the reigning king the former slave renamed the inclusive northern Sumatra polity Aceh. ${ }^{21}$

\section{Samudra-Pasai as a Commercial Center}

In the Hikayat Raja Pasai account the advent of SamudraPasai as the dominant Sumatra coastline port during the fourteenth and fifteenth centuries was subsequent to the decline of La-mu-li/Lamuri/Ramni to its north. Recent historians have paired this transition with Thai movements south into the Malay Peninsula during the twelfth and thirteenth centuries, as this resulted in the shift of Western Indian Ocean traders from the mid-Malay Peninsula coastline to northern Sumatra, initially to Ramni and then to Samudra-Pasai in the fourteenth century. ${ }^{22}$ These relocations are difficult to specifically determine since the only reports of Ramni after the thirteenth century were written by Chinese court scribes long after

20 D'Albuquerque, The Commentaries of the Great Alfonso D' Albuquerque, Second Viceroy of India, trans. By Walter de Gray Birch (London: 1875-1884),. 64.

21 The ambiguity of the Chinese information about the fall of Samudra-Pasai is due to the cessation of official communications between the two polities after 1434 or 1435, as after this date Ming interest in the commercial affairs in the South substantially subsided. See Groeneveldt, 211-15. The Ming government also discontinued the export of Chinese ceramics among other Chinese products, which created opportunities for enterprising Southeast Asian to fill this "Ming Gap." Roxanna M. Brown, The Ming Gap and Shipwreck Ceramics in Southeast Asia: Towards a Chronology of Thai Trade Ware (Bangkok: River Books, 2008). 
Samudra-Pasai's sixteenth-century decline. Fourteenth-century Yuan historians record the reception of envoys from La-mu-li (Ramni) and Samudra-Pasai at the Mongol court, and in the early fifteenth century the Ming eunach admiral Zheng $\mathrm{He}$ made stopovers at La-mu-li on each of his first six expeditions $(1405-1422){ }^{23}$ Samudra sent envoys to the recently empowered Ming court in 1403, responding to solicitation by Zheng $\mathrm{He}$, and from 1405 to 1424 sent tribute missions annually. There is no record of such a vigorous response to the Chinese gesture by the older port of La-m $u$ li/Ramni to the north.

It was not until 1412, when La-m u-li experienced the intervention of Zheng He's forces - pursuing a Samudra usurper - that La-mu-li began to send envoys to China. ${ }^{24}$ La$m u$-li then sent a mission to the Ming court annually until 1424, the same date that Samudra ceased its embassies. This was the time when the Ming dynasty abandoned its policy of maintaining a closely supervised tributary system in the Nanyang (Southern Seas), as it withdrew its support of China's lucrative sea trade.

Ming dynasty records suggest that La-mu-li yielded to Chinese pressure and only sent tribute missions when it faced an obvious threat, as when Samudra-Pasai 's encompassing authority over the northern coast was neutralized by a Chinese fleet. La-mu-li's seeming indifference to the Chinese in the Yuan and early Ming eras suggests that La-mu-li's profit from international trade was unrelated to the China market - but depended instead on its maritime relationship with the Western Indian Ocean as this stood in contrast to Samudra-Pasai's dependency on the extended Eastern Indian Ocean marketplace. In this view La-mu-li saw no need to establish a tributary relationship with China, or it was subject to SamudraPasai's commercial preeminence over the northern Sumatra coastline, thus minimally making La-mu-li Samudra-Pasai's commercial rather than political dependency. In the latter case 
it was appropriate that SamudraPasai and not its La-mu-li northern neighbor establish a tributary relationship with the Ming court as Samudra-Pasai was the then dominant port-oftrade on the northern Sumatra coast. Thereby La-mu-li, as a commercial subordinate of the Samudra-Pasai port-polity, would have traded with the Chinese at Samudra-Pasai rather than directly.

Zheng He's military intervention against La-mu-li poses several alternate conclusions. In one La-mu-li was a networked secondary commercial center to Samudra-Pasai in the Ming era, and was thus subject to Zheng He's military incursion against it, when La-mu-li was perceived to be a threat to Samudrai-Pasai, which had been consistently compliant with Ming demands. In an alternative view La-mu-li was previously the dominant port and Samudra-Pasai its secondary regional dependency prior to Zheng He's arrival. Thus Samudra-Pasai solicited Zheng He's favor by its calculated submission to Chinese demands, with the expected reciprocity that Ming troops would support Samudra-Pasai's sovereignty over Lamu-li. Ma Huan, who visited the region as a passenger on Zheng He's fleet, described La-mu-li as inhabited by over one thousand families, but that locally produced lakawood was the only commodity of consequence to be acquired at this port, and its population was mainly composed of coastal fishermen. ${ }^{25}$ As noted, Ma Huan characterized Samudra-Pasai as Yuan China's favored regional dependency.

Whatever the actual historical circumstances, by surpassing its competitor La-mu-li in the early fifteenth century Samudra-Pasai became the most important port-of-trade on the north Sumatra coastline. Thus Ibn Battuta's mid-fourteenth century account characterized Samudra-Pasai to be the favored port-of-call on the maritime passage from India to 
China. ${ }^{26}$ Ming historical records report that "merchants from all sides collect at this place, and as the country is distant and the prices high, the Chinese who go there make more profit than elsewhere." ${ }^{27}$ Among other early fifteenth-century accounts the Italian merchant Nicolo di Conti, who traveled to Southeast Asia in 1435 , described Samudra-Pasai as "a very noble emporium of that island [i.e., Sumatra]." 28 The Portuguese traveler Duarte Barbosa reported from India at the end of the fifteenth century that Samudra-Pasai ("Pansen") "has a most excellent port ... ." and was then known as the dominant commercial center on the Sumatra coast; ${ }^{29}$ by the early sixteenth century it was still "the principal port of the island of Sumatra" in Tome Pires' account. ${ }^{30}$

\section{Riverine System Exchange}

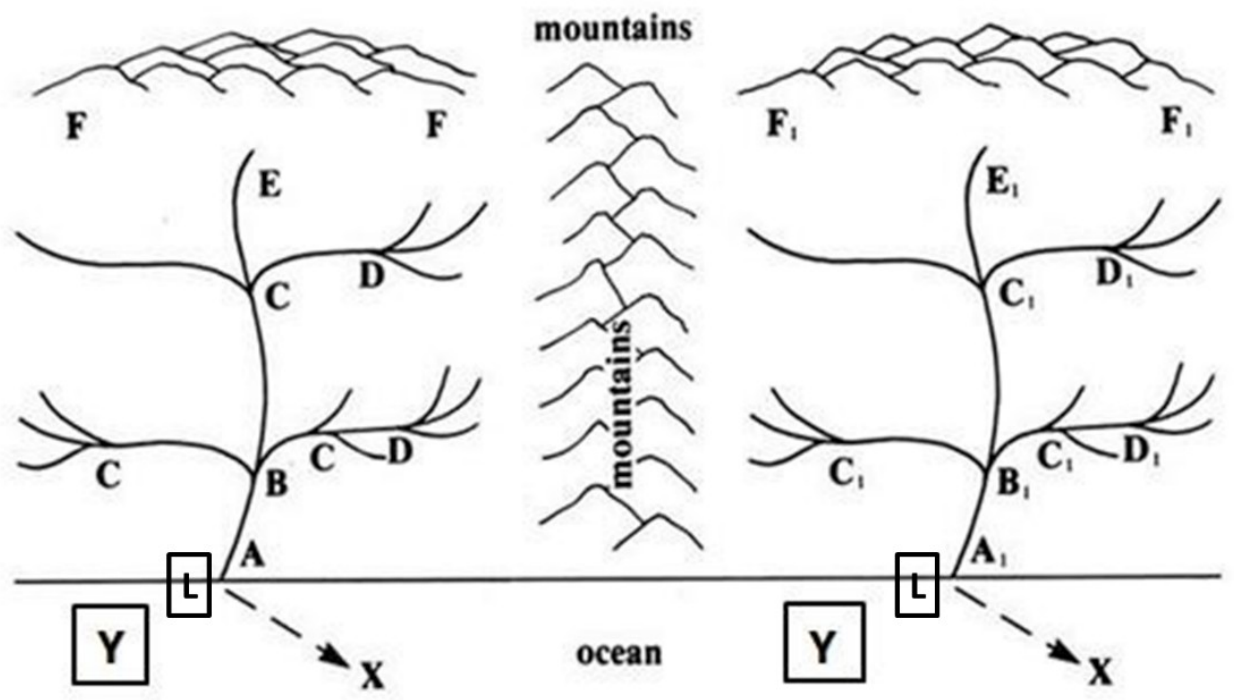

Figure 1: Riverine System Exchange in $15^{\text {th }}$ Century Samudra-Pasai ${ }^{31}$

26Ibn Battuta, 277.

27 Groeneveldt, 214.

28 Nicolo Conti, The Travels of Nicolo Conti in the East in the Early Part of the Fifteenth Century (London: 1857), 8.

29 Duarte Barbosa, The Book of Duarte Barbosa, trans. Mansel Longworth Dames (London: 1921), 185.

30 D'Albuquerque, 59.

31 Adapted from Bennet Bronson, "Exchange at the Upstream and Downstream Ends," in Hutterer, ed., 42. 
IV. Upstream-Downstream Networking in Fifteenth-Century Maritime Southeast Asia

This diagram of decentralized Southeast Asian riverine political systems is useful in understanding the dynamics of Samudra-Pasai's commercial and political stature as detailed in the cited variety of fifteenth- and sixteenth-century sources. In the Riverine Systems Exchange diagram (Fig. 1) a riverine system's trade "center" $(A)$ is located at a river mouth coastal base or a bit upstream at a strategic point $B$. In some cases, $A$ is on the coast in a swampy and sometimes saline marshland that is marginally productive as an agricultural center but ideal for fishing and a variety of other wetland productive activities, performed by a mix of resident coastal and diaspora communities. $B$ represents an upstream market and political center that in theory has better spatial security against coastal raiders, and has a strategic location relative to networked upstream cultivators or hunters and gatherers. Points $B$ and $C$ are otherwise secondary and third order centers located at upstream primary and secondary river junctions.

Point $D$ identifies more distant upstream centers, frequently key points of agricultural and hunting and gathering production in the typical Southeast Asia watershed. Points $E$ and $F$ are the extreme upstream producers, less- or non-market oriented population clusters of the upland or upstream hinterland villages and family clusters whose loyalty to the marketing system dominated by $A$ or $B$ at the regional river mouth is tangential. $A 1$ represents a rival river mouth center and its upstream marketing system. $A 1$ or $B 1$ can compete for the loyalty and product exchanges of the upstream Cs, Ds, Es, and $F$ s as well as for trade with $X$, a distant maritime and/or political center that consumes local exports and in return supplies consumables or monetary payments to the $A$ and $A 1$ riverine networks, or returns non-commercial redistributions or reciprocities, such as military protection and ritualized political and religious legitimation. $Y$ represents the settlements of offshore or extended harbor maritime diaspora communities who 
lived in boats or in homes on stilts, who in a variety of ways drew their income from the sea.

This hypothetical riverine system is integrated by coercion, whether based on political, military, marketing, or ritual networking. It may or may not be directly administered or colonized by $A s$ or Bs. As and Bs hold the loyalty of their marketing system by exacting oaths and/or tribute, or exercising their capacity to successfully select and confirm local membership and leadership. As and Bs will compete to establish and maintain dominance over their hinterland upstream networks as well as their offshore. $A$ relates to $B$ and the other upriver centers by emphasis on traditional mechanisms of alliance, but also depends on $X$ as a consumer of local products or as a supplier of foreign luxury and consumer goods, and as the ultimate source of the inclusive network's prosperity.

$X$ is the vital point in this networked exchange system, as it can acquire goods from each of several $A$ 's, selectively favoring a vital coastal center where foreign merchants can acquire the best quality or the best price, or ideally both. $X$ can shift its trade to a rival $A$ without regard for the acute economic or political hardships suffered by a downstream center temporarily deprived of trade, or $X$ can bypass $A$ to deal directly with the secondary networked interior centers of supply and thus circumvent the downstream centers and intermediaries. Points $A$ and $A 1$ are thus natural enemies, as it is in the best interest of one to establish political and market hegemony over the other. In such an instance $A$ 's control of A1's marketing network is not necessary. As long as $A$ controls $A 1, A$ will dominate the flow of trade goods to and from $A 1$ 's river mouth. $A$ 's dominance over $B 1$ could conceivably accomplish this same objective.

The projected riverine system includes the offshore resident maritime diaspora of Southeast Asia who live and derive their income from the sea, whether by fishing and other harvesting of the ocean, providing transport and naval services in times of peace, military services in times of war, or have the potential to engage in piracy in unstable times. Examples of these could include the "offshore mercenaries" who were active 
Malay Peninsula coastline seafarers and the orang laut maritime mercenaries who were the core of the fifteenthcentury Temasik military. In contrast to these offshore diaspora, there is a residential littoral $(L)$ community on the coastline that is neither exclusive to the land or the sea, as downstream landresident maritime diaspora, or otherwise coastal resident communities with varying land and residency rights, privileges, and community memberships. Michael Pearson qualifies these residents of the "littoral"l" $L$ " intermediate zone as consisting of sometimes residential and at other times fluid shoreline populations, who performed productive activities on the peripheries of " $A$ " coastal ports and networked areas of downstream cultivation, as represented in Figure 1. Occupants of this littoral may variably engage in maritime related activities, by managing fish ponds, tending salt flats, building and repairing boats, farming, and conducting other productive activities in coastal marshlands and otherwise marginally productive lands of the riverine network's coastal periphery. ${ }^{32}$ In contrast, the $Y$ s are distinct residential communities that occupy offshore space - as for example "floating villages" of seacraftbased activity zones and residencies. ${ }^{33}$

As documented in the Hikayat Raja Pasai and the variety of external sources introduced above, Samudra-Pasai embodies the riverine system model projected above and in Map 1. For example, Ibn Battuta's account cites a "port" activity zone he calls Sarha that was located at a point $A$ on the Samudra-Pasai coast said to be some four miles downstream from the core urban center of Samudra, in this instance the functional point $B$ of the Samudra-Pasai riverine system and in Ibn Battuta's time the residency of the monarch and his court. Samudra-Pasai's coincident urban marketplace and political center thus was a functional point $B$ in the riverine system model. Samudra and Pasai were strategic downstream court-

32 Michael Pearson, "Littoral Society: The Concept and the Problems." Journal of World History, 17, 4 (2006), 353-73.

33 Janet Gaynor, “Ages of Sail, Ocean Basins, and Southeast Asia,” Journal of World History, 24, 2, 2013, 309-33; Intertidal History in Island Southeast Asia: Submerged Genealogy and the Legacy of Coastal Capture, forthcoming, Cornell University Press. 
centered urban centers on the regional Pasangan and Pasai river systems, each of which flowed to the ocean from the conjunction of the upstream and downstream, thereby allowing the Samudra-Pasai rulers' dominion over product flows upstream to their Sumatra interior and downriver to the coast.

The nature of trade at Samudra-Pasai, although insufficiently documented in the Hikayat Raja Pasai, is described by others. An international community of merchant diaspora were seasonal residents at Samudra-Pasai - though there is no declaration of where they stayed, whether in semiresidential landed lodging in an "urban" center (points A or B in the upstream-downstream networked community model), in temporary lodging in the literal - whether on the coastline or in their temporarily anchored ships (L), or in boats clustered in offshore "residencies" (Y). In this regard Tome Pires cites among Pasai's fifteenth-century trade community - without providing details of their residential or non-residential status -Turks, Arabs, Persians, Gujaratis, south Indians (Klings), Malays, Javanese, Thai, Peguans [lower Burma], and Kedahans [from the western Malay Peninsula coastline]. ${ }^{34}$

Samudra-Pasai's growth as an urban center was dependent on forging and maintaining effective upstream and downstream networking, wherein its upstream hinterland was the source of pepper, camphor, and benzoin and other upstream commodities for the international traders who made stopovers at Samudra-Pasai's coastal port. That this relationship was successful is demonstrated in the foreign records that account the diverse commodities available to foreigners at the strategic Samudra-Pasai stopover. In the fourteenth-century Samudra-Pasai's advent as a commercial power was also dependent on its networked connections to India and China markets and points beyond. Certainly Samudra-Pasai's prominence was enhanced due to it positive embrace of Zheng He and his Ming fleet, followed by a series of confirming tributary missions to the Ming court. Zheng He's intervening military aggression against Samudra-Pasai's coastal competitor La-mu-li, and his well-established maritime 
networked connections to wider Indian Ocean trade circuits, resulted in Samudra-Pasai's designation as Ming China's preferred port-of-trade on the north Sumatra coastline as portrayed in the following graphic.

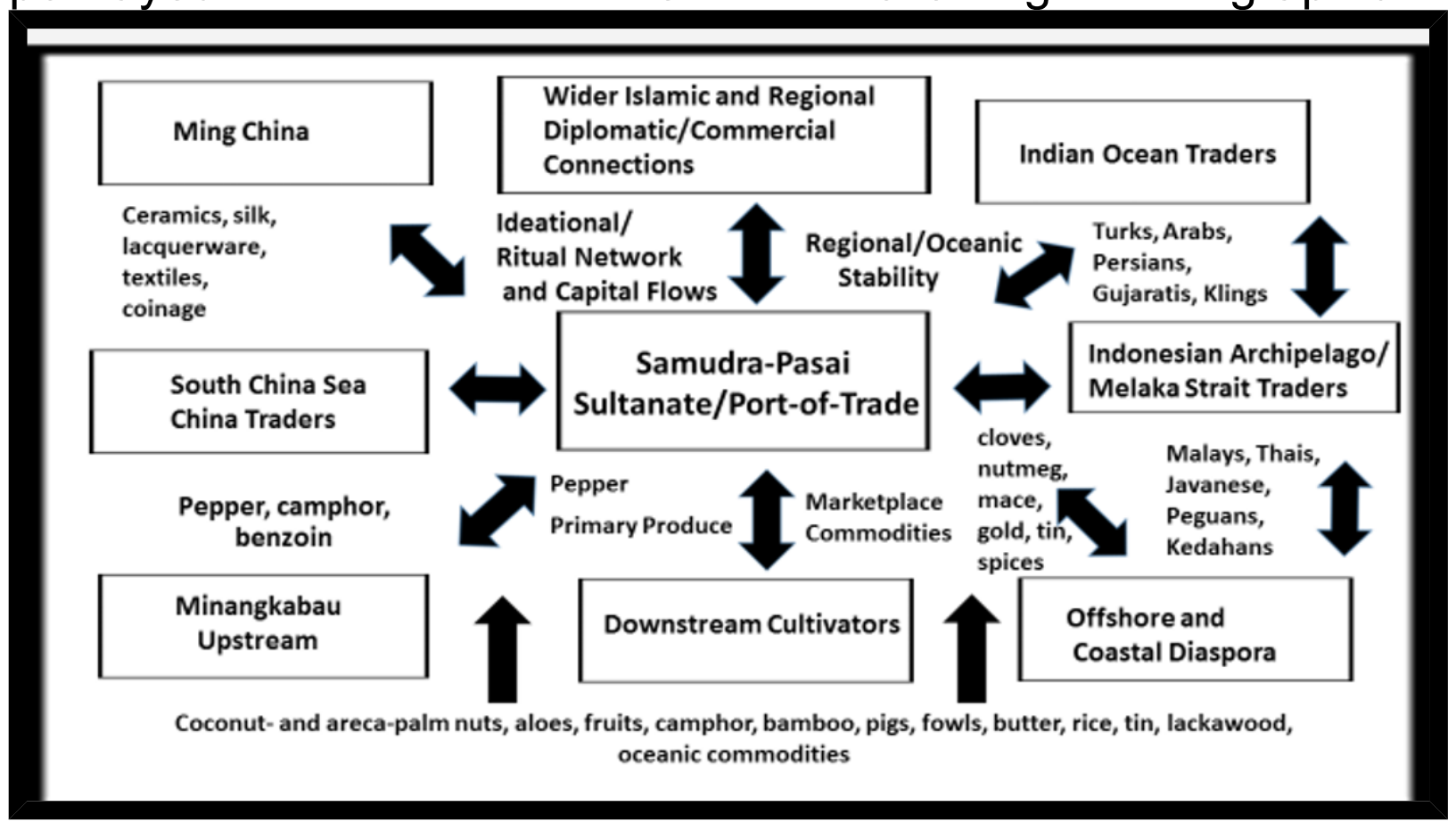

< FIFTEENTH CENTURY SAMUDRA-PASAI NETWORKING>

Unfortunately, there are only two surviving reports of Samudra-Pasai's subsequent international trade prominence. One is that of Ibn Battuta who was not overly interested in trade and depended on his memory for his accounts of his Indian Ocean travels; the second is that of Friar Odoric, who likely never traveled to Southeast Asia himself, but acquired his knowledge of Southeast Asia in early fourteenth century India. Odoric reports that Samudra-Pasai's reputation as a prosperous port of trade was high in India, and that SamudraPasai had a "great abundance of produce," naming among the available foodstuffs pigs, fowls, butter, and rice, in addition to the export of locally available gold, tin, pepper, and lackawood. ${ }^{35}$ His emphasis on foodstuffs documents a local trade in commodities for local consumption and provision of ships rather than a trade in luxury goods, which are normally focal in both Western and Chinese contemporary accounts of the maritime trade in other Southeast Asia's ports of trade. 
It would seem that the India coastline's early fourteenthcentury view of Samudra-Pasai, as reported by Odoric, was that Samudra-Pasai was an intermediary source of provisions for travelers passing through the Straits region rather than considering Samudra-Pasai to be a major source of substantive trade commodities. Notably missing is reference to SamudraPasai's importance as a primary or major intermediary source of Indonesian archipelago spices and Chinese products that were in greatest demand among India-based traders of that era. Thus Samudra-Pasai was initially a provisioning stopover for ships sailing onward to South China and Java Sea ports.

Odoric's reference to a local trade in metals is important, indicating that everyday transactions in precious and nonprecious metals were the norm in that era's marketplace. Iron deposits were notably absent in Java, several areas of Sumatra, and other regions of the Southeast Asia archipelago. That gold and tin were readily available in Samudra-Pasai and other Sumatra coast ports is attested in Odoric's report, as he describes their regular use as mediums of marketplace exchange. Since there is no account by Odoric that there was considerable bulk export of locally produced agricultural or other locally produced commodities to India, it would seem that Samudra was developing two levels of exchange, one based in the marketing of local consumables (e.g., food) to provision shipping passing through the Melaka Straits region to major East and West marketplaces, the other an international trade depending on the exchange of precious and non-precious metals for local products. ${ }^{36}$

Ibn Battuta acknowledged Samudra's emergence as a major international commercial center in his mid-fourteenth century account. His itemization of Samudra's exports included coco-palms, areca-palms, Indian aloes, various varieties of fruit, camphor, bamboo, tree incense, cloves, nutmeg, and mace. ${ }^{37}$ This list evidences considerable contact with other

\footnotetext{
36 See Derek Heng, "Export Commodity and Regional Currency: The Role of Chinese Copper Coins in the Melaka Straits, Tenth to Fourteenth Centuries," Journal of Southeast Asian Studies, 37, 2 (2006), 179-203.
}

37 lbn Battuta, 273. 
commercial centers not only along the Sumatra coast but also, and especially with Java. Camphor, for instance, is known as the major export of the western Sumatra coast prior to the fifteenth century, notably from Barus and its linked productive upstream plateau Minangkabau region, which was also fruitfully networked to Sumatra's east coast via a series of riverine and mountain trail passageways.

Saumdra-Pasai from the fifteenth century thus became the principal northwest coast port-of-call between northern Sumatra and the Sunda Straits. Cloves, nutmeg, and mace were all products of the eastern Indonesian archipelago that would have reached Samudra-Pasai via Java's ports. It would seem that this marketplace availability of spices was critical to the initial emergence of Samudra-Pasai as a major maritime entrepôt. The marketing of eastern Indonesian archipelago spices attracted western Indian Ocean merchants to SamudraPasai, eliminating the necessity of their onward travel to Java coast ports. But what was most unique about Samudra-Pasai among other Sumatra coast ports that most attracted the Western, Chinese, and Java traders?

Exploring the second part of this question in turn answers the first. Java's fourteenth-century commercial networking with the central Vietnam coastline and China to the north made the northern Sumatra coast strategically important to South China Sea and Java Sea commercial interests. In this time northern Sumatra pepper was much in demand among merchants servicing the China marketplace. ${ }^{38}$ Chinese maritime diaspora desired Sumatra's pepper, which was less expensive than that of India's Malabar coastline though inferior in quality. The Italian merchant sojourner Nicolo de Conti's early fifteenth-century report is the first Western account to stress Samudra-Pasai's role as that era's critical marketplace for the purchase of Sumatra pepper. ${ }^{39}$

The principle chronicler of Zheng He's early fifteenthcentury voyages, the Muslim translator Ma Huan, also reports

\footnotetext{
38 Schrieke, 24. At that time Chinese ships carried spices and pepper to China from north Java coast ports, especially Tuban.
}

39 As well us gold and camphor, see Conti, 9. 
that Samudra-Pasai was the strategic point-of-collection center for regional pepper. He describes Samudra-Pasai as a commercial center where "there are foreign ships going and coming in large numbers, hence all kinds of foreign goods are sold in great quantities in this country." 40 Ma Huan, who knew Samudra-Pasai during the time when Chinese influence in the Melaka Strait region was at its height, did not offer details on the variety of marketplace exchanges at Samudra-Pasai in a summary commentary on their productive "foreign" trade. Implicit in Ma Huan's omission of reference to Chinese traders' diverse activities in the northern Sumatra commercial realm was that by the late fourteenth century Samudra-Pasai was above all a prosperous intermediary center for the exchange of western and extended eastern Indian Ocean commodities notably goods arriving from India and those from Java Sea ports. Samudra-Pasai-based traders did not initially have a substantive direct trade with south coast China ports, but serviced ships arriving from eastern and western ports. Thus ships from Java Sea ports carrying eastern archipelago spices making Samudra-Pasai stopovers often sailed onward to China, supplying China's ports with Sumatra's pepper and western Indian Ocean commodities in exchange for China's products, which they returned to their Java coast "home" ports. Thus one reason for Zheng He's voyages into the Indian Ocean and stopovers at Samudra-Pasai and other Melaka Strait ports was China's perceived need to secure and promote commercial shipping between vital intermediary Straits of Melaka regional ports-of-trade and China.

Response to such a purposeful early Ming solicitation is represented in the tributary missions that Samudra-Pasai began to send to the Chinese court soon after Zheng He's first of four stopovers at the port on his first international voyage (1405-1407), but would end after his seventh voyage visit (1430-1433). Thereafter Ming authorities implemented a more indirect political and commercial relationship with Southeast Asia. ${ }^{41}$ Zheng He was also charged with suppressing piracy in the Straits, and soliciting stable allies in the Straits region to 
support China's interest in the free flow of international products into south China's ports-of-trade - to the pleasure of Chinese consumers, but above all to be taxed to the benefit of the Ming government. Consistent with what he perceived as being in the best interests of the Chinese public as well as the Ming state, notably achieving universal peace and stability, he was willing to intervene in the previously detailed SamudraPasai dynastic crisis, and pursued a deposed "usurper to the Pasai throne" to La-mu-li. ${ }^{42}$

By the middle of the fourteenth century Javanese cultural influence had reached Haru, Kampe, and Tamaiang on the southern Sumatra coast. ${ }^{43}$ That a networked Java relationship with Samudra-Pasai was continuous is well reflected in the Hikayat Raja Pasai as documented in the variety of evidence cited above. In the early sixteenth century, the Portuguese scribe Tome Pires, reflecting on the organization and history of Southeast Asian trade in the late fifteenth century prior to Portuguese conquest of Melaka in 1511, considered SamudraPasai to have been the fourteenth- and early fifteenth-centuries' most important northern Sumatra port, because it was at Samudra-Pasai that numerous Muslim merchants from the western Indian Ocean, Middle East, and South Asia intersected with traders from Java's markets. ${ }^{44}$ Samudra-Pasai's fourteenth- and early fifteenth-century significance in the Indian Ocean maritime trade was thus that of a major international marketing center where goods from the Western Indian Ocean and the Eastern Indian Ocean were exchanged, and especially Sumatra pepper and Indonesian archipelago spices. ${ }^{45}$ The founding of Melaka in 1402 would substantively negate Samudra-Pasai's regional prominence.

\footnotetext{
41 Geoff Wade on China trade

42 Ma Huan, 120-21.

43 Wolters, Fall, 43; Rita Rose De Meglio, "Arab Trade with Indonesia and the Malay Peninsula from the 8th to the 16th century," in D. S. Richards, ed., Islam and the Trade of Asia (London: 190), 115.
} 


\section{The Rise of Melaka}

Tome Pires exclusion of China merchants in his reported characterization of the prominence of Middle East and Javabased merchants in the Samudra-Pasai marketplace is significant. In his view Melaka had replaced Samudra-Pasai as China's preferred Southeast Asia trade intermediary shortly after its founding c. 1400 by Prince Paramesvara, a fugitive prince-consort who was chased out of the southeastern Sumatra and Singapore Island region by Majapahit's forces at the end of the previous century. ${ }^{46}$ The port-polity he founded was declared to be the heir to the maritime influence and power previously enjoyed by the earlier Srivijaya thalassocracy. Initially Melaka became significant as a facilitator of western Indian Ocean trade with China, but after Ming post-1430s withdrawal from aggressive participation in Southeast Asian affairs [including the end of Zheng He's voyages] Melaka was able to forge a new economic relationship with the Java coastline ports-of-trade, whereby multi-ethnic Java-based traders began to shift their spice trade from Samudra-Pasai to Melaka. Samudra-Pasai subsequently lost its reputation as the principle regional intermediary marketplace for the acquisition of Eastern Indonesian Archipelago spices and Sumatra pepper, and consequently by the end of the fifteenth century Indian Ocean merchants began to converge on Melaka to acquire Indonesian archipelago spices and other regional and international products.

\footnotetext{
45 The Chinese Xing Cha Sheng Lan (Description of the Starry Raft) account of Zheng He's voyages, composed in 1436, also confirms Semudra-Pasai's trade with China via Java, reporting among Samudra-Pasai's imports Chinese green and white celadon and silk and Javanese cloth (Groeneveldt, 210); pepper was said to be its major export. The ethnicity of the sojourners who transported the trade goods from Samudra-Pasai to Java and other regional destinations is not clear. Pires cites among Samudra-Pasai's fifteenth-century trade community Turks, Arabs, Persians, Gujaratis, south Indians (Klings), Malays, Javanese, Thai, Peguans, and Kedahans (Pires, 142, 44). He reports that no ships were built at the SamudraPasai port because of a scarcity of suitable wood (145); however its rulers owned laucharas, Javanese ships that carried Samudra-Pasai's trade commodities to destinations throughout the Indonesian archipelago.
}

46 See Wolters, Fall, passim. 
A corresponding increase in demand for Sumatra pepper in Western markets softened the impact of this shift of the Javanese spice trade away from Samudra-Pasai. Initially the Bengal region of India became a new market for SamudraPasai's pepper, ${ }^{47}$ and with greater Western activity in the Indian Ocean maritime routes throughout the fifteenth century the marketability of Sumatra pepper increased further. ${ }^{48}$ Tome Pires estimated Samudra-Pasai's annual pepper exports to number roughly 8,000 to 10,000 bahars per year at the beginning of the sixteenth century. ${ }^{49}$

In addition to pepper, the variety of surviving fifteenthcentury accounts demonstrate the diversity of commodities available at Samudra-Pasai. Samudra-Pasai was regarded as the collection center for Sumatra camphor from the central Sumatra Minangkabau upstream as an alternative to sailing to Barus on Sumatra's west coast. ${ }^{50}$ Samudra-Pasai was also the intermediary primary regional market for Indian products such as silk, as locally woven silk competed with Gujarat silk in regional marketplaces, ${ }^{51}$ benzoin,${ }^{52}$ gold, ${ }^{53}$ and silver. ${ }^{54}$ All kinds of other Sumatra products were said to have been available in Samudra-Pasai's markets, including rattan weaving fibers and various medicinals that derived from regional jungles. Tome

\section{Barbosa, 127.}

48 Barbosa, 185; Conti, 9; Groeneveldt, p. 210; D’Albquerque, 64.

49 Pires, 144. North Sumatra ports as a whole were exporting between 15,000 and 20,000 bihars of pepper annually, primarily to China, in comparison to the annual export of 20,000 bihars from the pepper fields of the southwest India Malabar coast to the west (Pires, 82, 139, 144). This evidence refutes the view of John Bastin, The Western Element in Modern Southeast Asian History (Kuala Lumpur: 1960), 13, that the Portuguese were responsible for shifting pepper cultivation from India to Southeast Asia. See Anthony Reid, "Trade and State Power in the 16th and 17th Century Southeast Asia" in Proceedings, 7th IAHA Conference, (Bangkok: 1979), 391-419.

50Conti, 9; Pires, 144.

51 Which appears to have been a local product, Pires, 144.

52 Pires,. 144.

53 Conti, 9; Pires, 144.

54 Pires, 144. 
Pires summarizes that "in Pase you will find all the merchandise there is in all the island, because it is collected there." 55 Thus, while Samudra-Pasai's role as the vital intermediary port in the Java and Indonesian archipelago spice trade diminished after the rise of Melaka, greater global demand for Sumatra pepper and other regional products sustained Samudra-Pasai's stature as an international Indian Ocean commercial center of note.

Samudra-Pasai's continuing success as a major sixteenthcentury port-of-trade was thus consequent to the concentration of the marketing of Sumatra's pepper production at SamudraPasai, which was dependent on Samudra-Pasai's continuing ability to draw pepper and other products from its upstream. Ma Huan described the "people who reside over against the mountains" as the source of Samudra-Pasai's pepper. ${ }^{56}$ Indeed the legend of Samudra-Pasai's founding recognizes a relationship between the coast and the interior as the source of its commercial stature. ${ }^{57}$ The legend relates the travels of a prince originally from northern Sumatra who resettled on the Samudra-Pasai coast, who subsequently journeyed upriver where he negotiated an alliance with the chiefs of the interior population. This prince is said to have been recognized as being royal and rich, and as a source of future prosperity. ${ }^{58}$ Having secured the backing of the interior leadership the adventurer then led a force composed of these chiefs and their warriors into the downstream, where they assisted the prince in his reassertion of his authority over the coast. Thereafter the hinterland chiefs retreated to their upstream homelands leaving the downstream domain to the prince, who became the first ruler of Samudra-Pasai.

55 Ibid.

56 Ma Huan, 118.

57 Hall, “The Coming of Islam," 223-27.

58 This story is likely symbolic or an agreement between the adventurer and the local leadership that the hinterland would support the prince's ambitions if he would share future prosperity with these chiefs and their followers. See Ibid. 
Applying the upstream-downstream riverine exchange model to this legend, Samudra-Pasai's new ruler may be seen establishing his authority over a point $A$ or $B$ (Samudra-Pasai and its port of Sarha in Ibn Battuta's account), but depending upon alliances with chiefs at upstream river points $C$ and $D$ as reported in the Hikayat Raja Pasai. These upstream chiefs had contributed to the new Samudra-Pasai ruler's rise to power, but then withdrew to their hinterland homes where they continued to maintain their traditional patterns of chieftainship and productivity. Ibn Battuta explains the difference between the coastal population and those of the upstream in Sumatra as being that of a Muslim coast and a "heathen" hinterland, ${ }^{59}$ a view confirmed by Friar Odoric. ${ }^{60}$

Ibn Battuta comments that the relationship between the upstream and downstream was not peaceful, as there was constant warfare that he attributed to the attempts of the Muslim coast to convert the "heathens" of the interior. But Ibn Battuta also acknowledged that Samudra-Pasai depended on the export of "aromatic plants" (pepper), which were to be found "in districts occupied by the infidels; in the Muslim [downstream] districts they are less plentiful." ${ }^{61}$ Camphor was also a product of this upstream. As noted, central Sumatra's upstream in the past had regularly sent their camphor to Barus, which was internationally known to have the best marketable camphor, but increased marketplace demand for camphor, the difficult passage of international sailors making the voyage up the west coast of Sumatra from the south, and Samudra-Pasai's variety of commodities that it could supply in trade to upstream suppliers, resulted in Samudra-Paai's having its share of the international camphor trade, as well as benzoin, another upstream product that came downstream to be exchanged for Samudra-Pasai's international products.

Certainly the periodic wars between the upstream and downstream considered by Ibn Battuta as being due to the

59 Ibn Battuta, 274.

60 Yule, 86.

61 Ibn Battuta, 273. 
religious fervor of the coastal regime were in reality economically motivated, as downstream rulers attempted to secure the "aromatic plants" from the upstream population to market in their port. Ibn Battuta adds credence to this depiction in his statement that the "infidels [here implying the upstream populations] pay the Muslim lords a poll-tax to secure peace. "62 This "poll tax" would seem to be a "tributary" upstreamdownstream networked redistribution relationship wherein the residents of the upstream were expected to provide commodities - notably pepper, camphor, benzoin, and other products of the distant Minangkabau region - which the residents of the downstream could market for export. When downstream deliveries were not made in a timely fashion it would seem that the upstream population was subjected to military expeditions by the downstream rulers to extract these commodities by force, as portrayed in Ibn Battuta's reference to the frequent raids by the downstream against the "heathen of the hinterland" suggests. That this upstream-downstream relationship was a repetitive problem in Samudra-Pasai's history is acknowledged in the Hikayat Raja Pasai chronicle, which accounts the periodic hostilities between the coast and upstream as political, rather than economic conflict. Tome Pires confirms that Samudra-Pasai remained a significant northeast Sumatra coast port-of-trade despite the frequent hostilities between the coastal port administrators and their upstream populations. ${ }^{63}$

The nature of this tension between the coast and its hinterland is further evinced in fifteenth-century reports that Samudra-Pasai had to regularly import food to feed its downstream commercial community, evidence that is quite contrary to that of Friar Odoric's view of early fourteenthcentury Samudra-Pasai. That Samudra-Pasai was importing food in the late fifteenth century is reported by Tome Pires, who states that Samudra-Pasai exempted all foodstuffs from import duties, while other imported goods were subjected to a $6 \%$

62 Ibid., 274.

63 Pires, 143. 
duty, ${ }^{64}$ and that annually sixteen junks of rice from the Pegu/Bago port-polity upstream from the Gulf of Martaban/Bay of Bengal, and thirty from Ayuddhya supplied Melaka and Samudra-Pasai before $1511 .{ }^{65}$

The first plausible implication is that Samudra-Pasai's upstream population was becoming specialized to the point that the production of pepper and other commodities for the international trade did not allow them time to tend to the production of foodstuffs sufficient for their subsistence. In a functional system the upstream population would have exchanged their variety of commercial products (e.g., pepper, camphor, benzoin, and gold) for imported commodities and downstream food, notably wet rice ${ }^{66}$ Failure to balance this systemic upstream-downstream reciprocal exchange would have resulted in the periodic upstream-downstream "raids" that are acknowledged in the local Hikayat and the accounts of foreign visitors (as depicted in the above graphic).

After it became a prominent international center for the export of pepper, Samudra-Pasai's marketplace significance was reinforced by its intermediary role in the re-export of the products of other Southeast Asian, Indian, and Chinese commercial centers. ${ }^{67}$ Despite the noted fifteenth-century accounts that report that Java's intermediary spice trade was re-centered from Samudra-Pasai to Melaka, the external

64 Ibid., 145.

65 Ibid., 98, I07.

66 Reid, "Trade and State Power," 397. Such commercial specialization and the consequent necessity of food imports became a pattern in other fifteenth-century Southeast Asian commercial centers. For instance Melaka depended on rice imports from Java, lower Myanmar, and Thailand while its population concentrated their energies on international commerce.

67 Miksic, Singapore and the Silk Road of the Sea, 129, 283, 334, who notes that there have yet to be significant excavations at Samudra-Pasai and Aceh. The contemporary Kota China in the central east coast Sumatra region site has provided substantive documentation of early trade in the Melaka Strait. See loc.cit., passim; John N. Miksic, and Yap Choon Teck, "Compositional analysis of pottery from Kota Cina, North Sumatra: implications for regional trade during the twelfth to fourteenth centuries A.D.", Asian Perspectives Vol. 31, no.1 (1992) , 57-76; and E. Edward McKibben, Kota Cina: Its Context and Meaning in the trade of Southeast Asia during the Twelfth to Fourteenth Centuries, PhD dissertation, Cornell University, 1984, and subsequent updates. 
sources collectively stress Samudra-Pasai's continuing and profitable role as the still prominent downstream collection center for Sumatra pepper and camphor. As previously cited, Tome Pires asserted that all the internationally desired upstream products of early sixteenth-century Sumatra were readily available in the Samudra-Pasai marketplace. ${ }^{68}$

Applying the upstream-downstream model, SamudraPasai's riverine commercial system based in $A$ and $B$ had with the exception of La-mu-li/Aceh established its commercial dominance at the expense of other Sumatra coast port-polities and their river systems (rival $A$ 's and $B$ 's) in dealing with foreign markets $(X s)$. Since the contemporary records collectively do not attest to Samudra-Pasai's assertion of political supremacy over rival regional river systems of ports-of-trade, SamudraPasai's emergence as a dominant and continuing prosperous commercial hub was ultimately dependent on Samudra-Pasai's pepper exports. In the latter instance this projected model would need to be modified to reflect an upstream-downstream network that drew foreign traders due to a single marketplace commodity, in this instance pepper, supplemented by the marketing of two much in demand secondary products, camphor and benzoin. In this instance Samudra-Pasai not only attracted international traders seeking these highly desired agricultural commodities, but it also drew traders who transported the products of other secondary regional river systems and ports-of-trade in the Straits of Melaka region. There they marketed their less-in-demand commercial products to the numbers of international traders seasonally active in the then prominent Samudra-Pasai port-of-trade.

Samudra-Pasai was then a "first order" if not dominant port due to its function as a supra-regional collection and marketing center in the strategic Straits of Melaka. It was clearly far more expedient for international traders to frequent only one regional port that could inclusively supply their variety of commercial needs. Thus Southeast Asia-based maritime traders initially carried Java's spices and China's products to Samudra-Pasai not only to acquire Samudra-Pasai's pepper, 
but also to make contact with Western Indian Ocean and Bay of Bengal traders, who because of the presence of Java marketplace specialties, especially eastern Indonesian archipelago spices, did not have to travel beyond the Melaka Strait to Java. ${ }^{69}$

Samudra-Pasai's networked marketing realm must have at its height included much of the northern and central Sumatra coastline, including Barus on the west coast as well as Ramni/La-mu-li (the future Aceh) on the northern tip of the island. ${ }^{70}$ Ibn Battuta sailed the Sumatra east coast for twentyone days on his mid-fourteenth century journey to China from Samudra-Pasai, and assumed that all the "countries" along the coast were also part of the Sultan of Samudra-Pasai's domain. ${ }^{71}$ A Pasai inscription dated 1389 claims SamudraPasai's authority over the ruling family of the Malay Peninsula's Kedah coastline, although there is no known contemporary evidence from Malay Peninsula sources to substantiate this claim; ${ }^{72}$ Ma Huan's account of the expeditions of Zheng $\mathrm{He}$ reports that he chased a Samudra-Pasai usurper to the northern Sumatra coast La-muli/Ramni realm in 1412, implying that Samudra-Pasai and La-mu-li were linked in some way, but also regional opponents. ${ }^{73}$ Thereafter La-mu-li began to send tribute missions to China, whereas only Samudra-Pasai had

69 Given the potential volatile nature of maritime trade diasporas in that era, this trading at a neutral port was likely preferable to the Javanese, eliminating any potential friction between the indigenous population and foreigners and preventing the visitors from assuming a role in local politics. As well it eliminated the necessity of providing facilities for a large number of visiting merchants and the problems in doing so. Resulting frictions between port commercial interests and indigenous rulers are discussed below.

70 This does not, though, indicate political subjugation; see Wolters, Fall, 46, who regards none of the northern Sumatra port-polities in that era as being politically dominant until the rise of Aceh in the early sixteenth century.

71 Yule, 468.

72 Hill, "Hikayat," 21-22. Pasai may be viewed as the successor to Kedah coast ports as the then dominant intermediary in trade with Western traders. See Hall and Whitmore, 310). In this light Pires' reference to the residents of Pasai, including a maritime/trading community he regards as being based on the Kedah coast may be significant in sorting out the various trading interests and participants in this transitional era (see note 78, above).

73 Ma Huan, 120-21. 
been previously sending envoys. These events were a prequel to the future, as by the end of the fifteenth century SamdraPasai was annexed into the Aceh sultanate. ${ }^{74}$

\section{The Samudra-Pasai Marketplace}

In his fourteenth-century account Ibn Battuta reports the role of the Samudra-Pasai ruler's representative (minus specific details on his ethnicity or residential status) as the supervisor of its port trade. Tome Pires elaborates in detailing the early sixteenth-century Samudra-Pasai ruler's considerable derived state revenues from the port-polity's trade. At that time the ruler's agents levied an export duty of one maz of gold (1/16 ounce) per every bihar of merchandise. ${ }^{75}$ In contrast, a colleague of Ma Huan in the prior century reported that such duties were not normally collected in gold, but were paid in pepper, which was then marketed by the ruler's agents. ${ }^{76}$ The variety of external sources are in agreement that local duty collections, whether in gold or in commodities, were a substantive source of the Samudra-Pasai court's income. A prosperous pepper trade thus doubly benefited the SamudraPasai rulers: high marketplace volume increased the rulers' collections of export duties, paid in pepper, which was then marketed by the rulers' marketplace agents. Substantial marketplace demand for pepper thus brought high prices and produced increased profits not only to Samudra-Pasai's traders as also its rulers. ${ }^{77}$

Samudra-Pasai's ruler also levied an anchorage fee on all shipping entering his port-polity's harbor, the rate determined according to the size of the ship. Imports were subject to a duty of $6 \%$, except for foodstuffs that were exempted. ${ }^{78}$ According to

74 Miksic, Singapore and the Silk Road of the Sea, passim.

75 Ibid., 145.

76 From the Tung Hsi Yang K'au, quoted in Groeneveldt, 199.

77 Indeed, Chinese sources of this era are consistent in their declarations of the high profits accruing to all who participated in Pasai's pepper trade. See Groeneveldt, 214. 
the Xingcha Shenglan [The Overall Survey of the Star Raft] 1436 report of Zheng He's voyages, goods in greatest demand at Samudra-Pasai were Chinese celadon ceramics and colored silks, Java-cloth (batik?), copper, and iron, as these were each considered appropriate for royal consumption, as also patronage redistributions to the Samudra-Pasai monarch's networked supporters. There is no definitive evidence depicting the extent of the Samudra-Pasai ruler's direct or indirect participated in marketplace trade, but it is certain that he must have profited from noted redistributions of foreign commodities, which in turn sustained his upstream networking relationships that assured his port-marketplace's security and access to much-in-demand upstream products. ${ }^{79}$ Tome Pires reports that although no ships were built locally, Samudra-Pasai's rulers personally owned small ships (lancharas) that carried Samudra-Pasai marketplace commodities to various destinations within the archipelago. ${ }^{80}$ Pires may have mistakenly attributed these small ships as belonging to the Samudra-Pasai ruler. These ships were most likely the property of independent multi-ethnic maritime diaspora (including Malay seamen) who transported goods among the ports of the archipelago, but who in this instance were based in SamudraPasai's port. While it would appear that the Samudra-Pasai ruler or his representatives directly participated in trade via their collection of port cesses paid in kind (most notably in pepper), ${ }^{81}$ Samudra-Pasai's monarch never held a monopoly over the exchange of Samudra-Pasai's pepper or other marketplace commodities, though as noted he had taxable rights to some of the profitable pepper and other marketplace commodities.

Also notable is that in almost all the records of SamudraPasai's imports and exports there is cross-reference to metals,

79 That such cesses were important to Malay rulers is indicated by the common penalty for evasion of port cesses was the enslavement of the offender. See Windstedt and de Jong, 54.

80 Pires, 145.

81 Against this John Miksic, Singapore and the Silk Road of the Sea, 334, cites Ma Huan's record that tin coins were used in Samudra-Pasai and Aceh north Sumatra coastline marketplaces c. 1425-1432, though this has not been substantiated in subsequent local excavations, which have included tin(as there were local tin deposits) but no tin coinage. 
notably gold, tin, silver, and iron as important marketplace exchange commodities, as these commodities are this is consistent with the recovered remains of shipwrecks from this era. ${ }^{82}$ Friar Odoric's early fourteenth-century account is the earliest, listing gold and tin as valued marketplace commodities available at Samudra-Pasai. ${ }^{83}$ Ibn Battuta's mid-fourteenthcentury record declares that the inhabitants of Samudra-Pasai regularly conducted their trade using "pieces of tin and native Chinese gold, unsmelted." 84 There is no report of the source of these metals. Did the tin come from Sumatra or Malay Peninsula mines and the gold from China, ${ }^{85}$ from local mines, or does reference to the exchange of metals at Samudra-Pasai document Samudra Pasai's marketplace participants conducting trade not in kind, as was once believed, but regularly utilized precious metals as a medium of exchange?

Is it possible that the surviving narrative evidence documenting the exchange of metals for export commodities reports only the activities of Samudra-Pasai's international commercial community within Samudra-Pasai's marketplace,

\begin{abstract}
82 Derek Thiam Soon Heng, "Export Commodity and Regional Currency: The Role of Chinese Copper Coins in the Melaka Straits, Tenth to Fourteenth Centuries," Journal of Southeast Asian Studies, 37, 2, 2006, 179-203; Roxanna Brown, "The Ming Gap and Shipwreck Ceramics in Southeast Asia," Ph. D. diss., UCLA, 2004, 23-24 on the late fourteenth-century Rang Kwien shipwreck in the Gulf of Thailand, which had substantive Chinese coinage. See also Derek Heng, "Trans-Regionalism and Economic Co-Dependency in the South China Sea: The Case of China and the Malay Region (tenth to fourteenth centuries AD)," International History Review, 35, 3 (2013), 486-510. As Heng notes: Taking together the development of Chinese maritime trade in South-East Asia, the development of a low-denominational currency in Java that was based on Chinese copper specie, and the regional economy that was developing between the Malay region, Java, and South China by the fourteenth century, it is likely that an informal and rudimentary regional currency system, based on the Chinese copper coin, may have resulted as a means to facilitate the increased economic interaction in the South China Sea region. (504).
\end{abstract}

83 Yule, 86.

84 Ibn Battuta, 273. The Xing Cha Sheng Lan ("Description of the Starry Raft") account of Zheng He's voyages (1436) that reports the import of copper and iron (Groeneveldt, 210). Gold is said to be in abundance at Samudra-Pasai in the same era by Conti, 9, while Pires reports the use of silver in c. 1500 Samudra-Pasai exchanges (Pires, 144).

85 China was in this age known to be exporting gold to Southeast Asia to acquire Southeast Asian commodities -- a matter of concern among Chinese officials as this would ultimately ruin the Chinese economy. North Sumatra was widely known as a source of gold and tin in this era. 
where metal and/or coinage transfers regularly took place in the acquisition of goods for export? In contrast, regular market exchanges for goods for immediate consumption, such as foodstuffs, were more likely transacted in kind. Such distinction of the variety of marketplace transactions is supported by the external narrative reports that Samudra-Pasai officials valued exported goods in gold, suggesting that metallic values were commonly used in pricing export commodities. But the fact that local assessments were said to be collected in kind, while there is nothing to suggest that referenced anchorage fees and import duties were collected after first establishing their metallic values indicates that there were multiple types and complexities of exchanges taking place. ${ }^{86}$

VII. The Rise of Melaka and the Demise of Samudra-Pasai

Melaka was founded around 1400 by Parameswara (c. 1344- c. 1414), the last Maharaja of Temasik (present-day Singapore), as this rival port-polity was destroyed by a Majapahit naval attack in 1377. By 1409 the displaced monarch took the title Iskandar Shah as the Sultan of Melaka, and reinforced his regional legitimacy by marrying a Samudra-Pasai princess. Melaka benefitted from its accessibility and strategic location at the narrowest point of the Melaka Straits, and solid backing by the Ming Emperor Yongle (1402-1424) and his Admiral Zheng He, who personally presented the Melaka ruler to the Emperor at the Ming court in 1411. The shift of the Javanese spice trade to Melaka was chiefly responsible for wider transition in Southeast Asia-wide commercial patterns. Melaka, with the support of Java's rulers, multi-ethnic maritime diaspora sojourners, and China's emperors, became the paramount Southeast Asia port-of-trade by the second quarter of the fifteenth century.

Java-based traders not only traded spices at Melaka, but also supplied Melaka with Java's rice to sustain Melaka's increasing urban population. Multi-ethnic Indian Ocean maritime diaspora joined the Java-based traders as long-term 
and seasonal residents in Melaka, as Melaka displaced Samudra-Pasai as the critical intermediary marketplace for the exchange of Eastern and Western Indian Ocean products. As Melaka rose to prominence numbers of merchants who were based on the Sumatra coast and formerly traded at SamudraPasai shifted their commercial activities to the Melaka port. The exceptions were riverine centers on the northern and central Sumatra coasts, which had some degree of trade with Melaka but were otherwise in regular contact with a variety of foreign traders. ${ }^{87}$

One important factor that provided Melaka an advantage over Samudra-Pasai was the relative security of the emerging Melaka port in contrast to Samudra-Pasai's strategic vulnerability. During the early period of Melaka's history it was threatened by the Thai, ${ }^{88}$ but Melaka's tributary status to the Ming court and Zheng He's frequent presence in the Strait assured the security and stability of the Melaka port. ${ }^{89}$ Surviving Malay chronicle sources agree that Melaka was attacked by Thai forces attempting to reestablish Thai interests over the lower Malay Peninsula in the early fifteenth century, but the Thai were never able to take their land and naval forces near Melaka itself. ${ }^{90} \mathrm{~A}$ Thai source, while confirming that there was an intended attack on Melaka is silent about the result, thus indicating its failure. ${ }^{91}$ The Sejarah Melayu Melaka chronicle reports the defeat of the rival Patani-based orang laut fleet that attacked Melaka on the Thai Ayutthaya court's behalf, but was

87 Pires, passim; D'Albuquerque, passim.

88 In the Sejarah Melayu the Thai are characterized as Melaka's primary enemy.

89 Thus the Chinese not only neutralized the Thai, but also the Javanese. See Wolters. Fall, 168-69.

90 See the Sejaruh Melayu and the Hikayat Hang Tuah, the latter a retrospective literary account of Melaka's origins focal on the hero Hang Tuah, who serves the Melaka court including leading diplomatic visits on Melaka's behalf at courts of the Keling (southeast India), China, Mecca, Egypt, and Rome.

91 See the Thai Luang Praseri Chronicle. This information was supplied by Nidhi

Aesrivongsa of Chiengmai University. Despite this disorder, Pires reports that ". . . there is no disturbance whatever in the city or among the (city residents) and merchants whether king be killed or alive," suggesting a stable urban community. 
intercepted by Melaka's naval forces far away from Melaka, and Melaka troops were subsequently victorious over Thai forces in the Pahang region of the northern Peninsula. Henceforth Melaka was depicted in a variety of contemporary sources as providing security from external attack to traders frequenting its port, until the Portuguese took possession of Melaka in 1511.

Melaka's fifteenth-century political stability is celebrated in the Sejarah Melayu, with no record of attempted usurpations or internal political strife. Instead the Melaka chronicle confirms the successful establishment of a secure regional setting for international trade. Melaka's legitimacy was formalized in an alliance with the full-time and seasonal resident diaspora populations; the Sejarah stressed this multicultural tranquility as the source of Melaka's prosperity, as also the importance of the Melaka port's functional legal codes. While Melaka's rulers guaranteed the necessary security for trade, in reciprocity the traders in turn agreed to observe a set of rules governing the proper conduct of their trade and residency as members of Melaka's urban community. The Undang-Undang Melaka civil code paired with the maritime code of conduct, the UndangUndang Laut Melaka that applied to international shipping that anchored at the Melaka emporium. ${ }^{92}$

The record of peace and security in Melaka stands in contrast to the history of Samudra-Pasai as reported in its Hikayat Raja Pasai dynastic text. The Samudra-Pasai chronicle makes it seem that trade was conducted at the Samudra-Pasai port-of-trade despite the port-polity's numerous instabilities and vulnerabilities. The Samudra-Pasai Hikayat court chronicle focuses on continuous internal family conflicts, political feuds, unstable relationships between the downstream court and its upstream and coastline, and periodic disorder within the inclusive Samudra-Pasai realm. Royal family conflicts took place in every generation and collectively this dysfunctionality is the comprehensive theme of the Hikayat's story. The reality of Samudra-Pasai's local political instability was consistently

92 James Reddie, An Historical View of the Law of Maritime Commerce, London: W. Blackwood and Sons, 1841. 
acknowledged in the accounts of foreigner visitors. The early fifteenth-century Portuguese Indian Ocean traveler Duarte Barbosa noted, for example, that "the Moors of Samudra-Pasai are very treacherous and ofttimes murder their own kings and set up others." ${ }^{\prime 3}$ Ma Huan confirmed this evidence of periodic crisis in his previously cited account of a Chinese intervention to resolve a Samudra-Pasai dynastic feud during the early fifteenth century, when Zheng He's forces chased a potential usurper to the Samudra-Pasai throne into the neighboring upstream territory of La mu-li [future Aceh] to the north. Tome Pires may exaggerate the situation in his early sixteenthcentury report that it was customary in Samudra-Pasai that "who kills the king becomes king," but follows with what he declares as the truth that "they say that on one day [in the past] there were seven kings in Pase." 94

Sometime during the late fifteenth century the center of Samudra-Pasai authority moved further inland, perhaps as a result of a victory by a branch of the royal family that had its power base in the upstream. ${ }^{95}$ Pires alludes to a plausible reason for this move to the interior in the context of his report of frequent quarrels between the upstream populations and the coastal administration. ${ }^{96}$ He conceives the shift of the political center of Samudra-Pasai's further upstream from the coast, as making it less vulnerable to a maritime attack. The SamudraPasai ruling elite thereafter had their power base among the people of the upstream. ${ }^{97}$ As cited, Samudra-Pasai's origin myth is based in a foundational alliance between these two populations. During most of the course of Samudra-Pasai's

93 Barbosa, 189.

94 Pires, 143.

95 Hill, "Hikayat" 143. The archaeological remains of Pasai's royal court are still in existence inland from the coast. Hill argues that the shift of the court to the interior was due to periodic pirate attacks, but no other report of this problem is found other surviving sources. In looking for external reasons for the inland move of the court is suggested in Pires' retrospective account record of a late fifteenth century conflict between Sumudra-Pusai and Pedir, a rival pepper emporia on the northern Sumatra coast, which Pires identifies (Pires, 139), as there is also remaining legend of Pasai's conflict with Nagur and its "taloned-faced ruler."

96 PIres, 143. 
documented history, this relationship between the coast and its upstream always existed on a potentially volatile threshold. One can speculate that the move of the royal center of SamudraPasai to its upstream was not entirely due to another succession crisis, but the result of a takeover of the SamudraPasai throne by elite partners of the interior populations, who had previously been marginalized by previous downstream rulers and their networked littoral supporters. ${ }^{98}$

Tome Pires retrospectively reports the late fifteenth century demise of Samudra-Pasai began with the shift of the previously allied Sumatra coastline pepper port of Pedir's allegiance to Melaka. ${ }^{99}$ Subsequently the upstream Nagur realm shifted its loyalty to Pedir, which had links to the productive Miningkabau upstream, and consequently tried to attract traders to its river mouth port as an alternative to Samudra-Pasai. ${ }^{100}$ These shifting patterns of marketplace and upstream-downstream alliance are consistent with the previously cited model of regional riverine system statecraft, as the downstream Pedir and upstream Nagur riverine systems transitioned from their prior alliance with Samudra-Pasai. Ultimately in the early sixteenth century the remnant of the Samudra-Pasai riverine network came under the authority of the emerging north Sumatra Aceh sultanate, which by 1500 had replaced Samudra-Pasai as the dominant marketing center of north Sumatra's pepper trade. ${ }^{101}$

Samudra-Pasai's rulers sustained themselves by becoming suppliers of pepper rather than as the traders of commercial goods, began to refocus Samudra-Pasai's

97 "Great nobles of the kingdom, who are called mandrin, and the men-at-arms" live inland. Ibid.

98Aceh remained the dominant force in the northern Sumatra pepper and commercial spheres until the late nineteenth, as also the center of Southeast Asia Islam. See Snouck Hurgronje, The Achchnese, trans. by A.W.S. O'Sullivan (Leiden: 1906).

99 Pires, 139.

100 Ma Huan, 115-18; Hill, "The Coming of lslam to North Sumutra," 7-10.

101 Aceh remained the dominant force in the northern Sumatra pepper and commercial spheres until the late nineteenth, as also the center of Southeast Asia Islam. See Snouck Hurgronje, The Achenese, trans. by A.W.S. O'Sullivan (Leiden: 1906). 
economic system on the production of commodities for foreign markets, especially pepper, rather than continuing as a marketing agent of the trade itself. This internalization of Samudra-Pasai's regional commerce was in part a response to the changing conditions of trade in the Melaka Strait. Portuguese conquest of Melaka in 1511 and the consequent establishment of Portuguese commercial sovereignty in the Melaka Strait passageway contributed to the final demise of Samudra-Pasai as a primary commercial power. Aceh's increasing success as the dominant port on the northern Sumatra coast was due to its internal order and, similar to Melaka, an alliance between its commercial sector and its rulers. ${ }^{102}$ Aceh's resulting political and economic strength, reinforced by Aceh's stature as the regional center of Islam, allowed Aceh to dominate what had previously been SamudraPasai's upstream-downstream realm and successfully avoid subordination to European commercial interests due to its prominence in the Indian Ocean Islamic network. ${ }^{103}$

102 See Reid, "Trade and the Problem of Royal Power in Aceh."

103 Lambourn, "The Formation of Batu Aceh." 